\title{
Characterization of Moenomycin Antibiotic Complex by Multistage MALDI-IT/RTOF-MS and ESI-IT-MS
}

\author{
Martin Zehl and Ernst Pittenauer \\ Institute of Chemical Technologies and Analytics, Vienna University of Technology, Vienna, Austria
}

\author{
Andreas Rizzi \\ Institute of Analytical Chemistry and Food Chemistry, University of Vienna, Vienna, Austria \\ Guenter Allmaier \\ Institute of Chemical Technologies and Analytics, Vienna University of Technology, Vienna, Austria
}

\begin{abstract}
Flavomycin is a commercially available antimicrobial growth promoter and an authorized additive for feeding stuffs in the EU and in the USA. As most antibiotically active products biosynthesized by microorganisms, it contains not only a single active compound but is a complex mixture of structurally closely related substances. Multistage matrix-assisted laser desorption/ionization-ion trap/reflectron time-of-flight mass spectrometry (MALDI-IT/ RTOF-MS) and liquid chromatography-electrospray ionization-ion trap-mass spectrometry (LC-ESI-IT-MS) were utilized for a detailed analysis of the constituents of the Flavomycin complex based on low-energy collision induced dissociation (CID). An optimal sample preparation for negative ion vacuum MALDI-MS for this compound class was developed. The MALDI-IT/RTOF-MS ${ }^{2}$ and $-\mathrm{MS}^{3}$ analysis starting with the precursor $[\mathrm{M}-\mathrm{H}]^{-}$ions of these interesting phosphoglycolipids, named moenomycins, yielded a large variety of product ions that facilitated the structural characterization of this class of compounds. Based on the derived CID fragmentation pathway of the five known major constituents, namely moenomycin $\mathrm{A}$, moenomycin $A_{12}$, moenomycin $C_{4}$, moenomycin $C_{3}$. and moenomycin $C_{1}$, four not yet described moenomycin-type constituents could be characterized. They were assigned as $4 \mathrm{~F}$-demethyl-6E-O-de- $\beta$-D-glucopyranosyl-moenomycin A, 6B-N-de(2-hydroxy-5-oxo-1cyclopenten-1-yl)-moenomycin A, 6B-hydroxy-6B-de[N-(2-hydroxy-5-oxo-1-cyclopenten-1yl)amino]-moenomycin $\mathrm{A}$, and 6C-hydroxy-moenomycin $\mathrm{A}$. In addition, a moenomycin $\mathrm{A}$ carrying an oxygen in the moenocinol-group was found, which is most probably a chemical degradation product. These new compounds were verified by LC-ESI-IT-MS. (J Am Soc Mass Spectrom 2006, 17, 1081-1090) @ 2006 American Society for Mass Spectrometry
\end{abstract}

$\mathrm{M}$ oenomycins, alternatively named bambermycins, Flavomycin, and flavophospholipol, are a group of structurally very similar phosphoglycolipid antibiotics produced by several Streptomyces species, including S. bambergiensis, S. ghanaensis, S. geysiriensis, and S. ederensis [1-3]. The spectrum of antibiotic activity of the Flavomycin complex covers primarily gram-positive microorganisms, such as staphylococci and streptococci [2, 4]. It is used as antimicrobial growth promoter of several farm animals [2] and is an authorized additive for feeding stuffs in the EU (registration number E 712) [5] and in the USA [6].

The antibiotic activity of the moenomycins is based

Published online May 30, 2006

Address reprint requests to Dr. G. Allmaier, Institute of Chemical Technologies and Analytics, Vienna University of Technology, Getreidemarkt 9/164-IAC, A-1060 Vienna, Austria.E-mail: guenter.allmaier@tuwien.ac.at on the inhibition of the bacterial cell wall formation [2, $3,7,8]$. The biosynthesis of the peptidoglycan in the cell wall involves the assembly of lipid II (the disaccharide pentapeptide monomer unit that is linked to an undecaprenyl phosphate-membrane carrier) from cytoplasmic intermediates, the translocation of lipid II through the cytoplasmic membrane to the outer surface followed by the incorporation of the disaccharide pentapeptide monomer units into the growing glycan chains (transglycosylation) and finally the formation of the peptide cross-bridges to the pre-existing peptidoglycans in the mature cell wall (transpeptidation) [8]. The moenomycins interfere with the transglycosylation reaction by inhibition of some membrane-bound, nonpenicillin-binding, monofunctional glycosyltransferases (Mgts) and some class A high-molecular-mass penicillin-binding proteins (HMM-PBPs) [2, 3, 7-12]. Class A HMM-PBPs, such as the PBP1b from Escherichia coli, are 


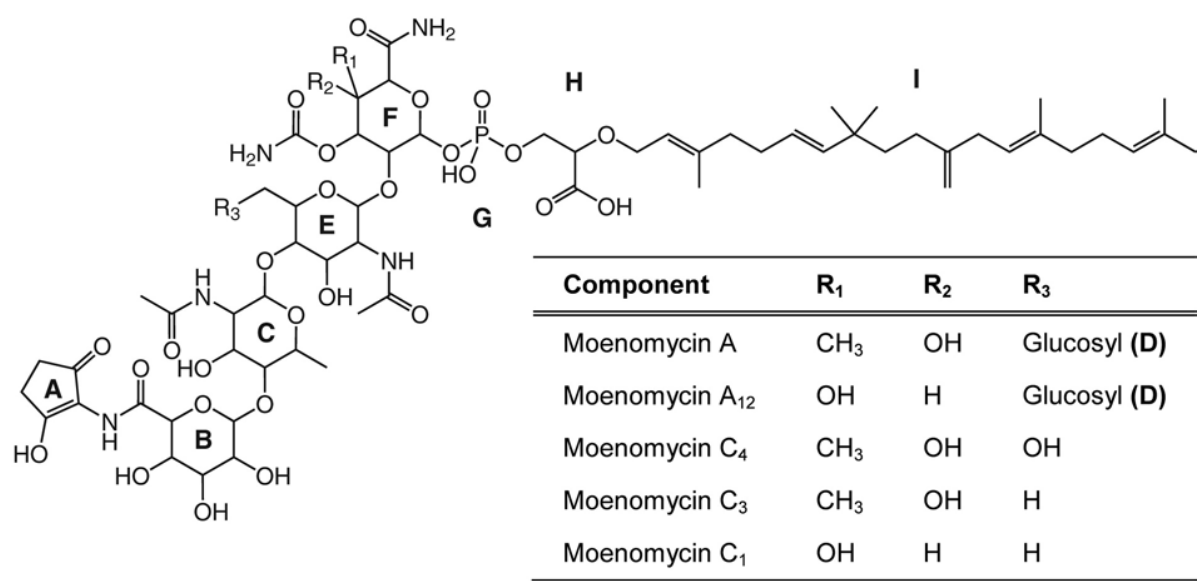

Scheme 1. Structure of the five previously characterized moenomycin antibiotics that are known to constitute the Flavomycin complex.

two-domain proteins that catalyze both the transglycosylation reaction and the transpeptidation reaction. While $\beta$-lactam antibiotics bind covalently to an activesite serine in the transpeptidase domain of this bifunctional enzymes, moenomycins are assumed to act as competitive inhibitors at the transglycosylase domain $[3,7-10]$. Although several antibiotics interfere with the transglycosylation reaction, moenomycins are the only compounds known to date that directly interact with the transglycosylases rather than bind to their substrates [3]. The moenomycins therefore represent an interesting template for the design of new antibiotic drugs $[3,7,8,13,14]$, which are highly desired because of the problem of bacterial resistance [14-18].

Now, five major components of the Flavomycin complex have been structurally characterized, namely moenomycin A [19-21], moenomycin $\mathrm{A}_{12}$ [22], moenomycin $C_{4}$ [23], moenomycin $C_{3}$ [23], and moenomycin $\mathrm{C}_{1}$ [24]. They all consist of a central oligosaccharide part (B-F) that is, on the one side linked to an isoprenoidlike $\mathrm{C}_{25}$-alcohol (I) via a phosphodiester group $(\mathbf{G})$ and a 2,3-dihydroxypropanoic acid (glyceric acid) group $(\mathbf{H})$ and, on the other side to a 2-hydroxy-5-oxo-1-cyclopenten-1-yl group (A) (Scheme 1). From structureactivity relationship analysis, it has been found that moenomycin trisaccharides containing the units C, E, F, G, H, and I are the smallest fragments that show antibiotic activity in vivo, whereas moenomycin disaccharides containing the units E-I still act as transglycosylase inhibitors in vitro $[3,7-9,12,25]$. The isoprenoidlike $C_{25}$-alcohol [26], named moenocinol, seems to be required for the binding of the moenomycin antibiotics to the cytoplasmic membrane [27], whereas the units E, $\mathbf{F}$, and $\mathbf{H}$ are concluded to form a polar binding epitope that is recognized by the donor binding site of the transglycosylases [3, 7-9, 19, 28]. In addition to the five known constituents of the Flavomycin complex, structurally related moenomycin-type antibiotics, including the prasinomycins, the diumycins (macarbomycins), ensanchomycin, prenomycin, teichomycin, pholipomy- cin, AC326- $\alpha, 11837 \mathrm{RP}, 8036 \mathrm{RP}$ (quebemecin), and $19402 \mathrm{RP}$, have been found [3, 23, 29, 30].

The chemical structures of the five major components of the Flavomycin complex have been established by ${ }^{13} \mathrm{C}$-NMR spectroscopy and fast-atom-bombardment (FAB)-mass spectrometry (MS) of the purified compounds [20-24] and were later confirmed by ${ }^{1} \mathrm{H}-\mathrm{NMR}$ spectroscopy [31]. Subramaniam-Niehaus et al. [32] have used liquid chromatography-electrospray ionization-mass spectrometry (LC-ESI-MS) to confirm the presence of these five compounds in the culture filtrate of S. ghanaensis. Recently, Eichhorn and Aga [6] isolated the moenomycin antibiotics from medicated chicken feed and investigated the fragmentation behavior of the five known constituents by positive and negative ion mode LC-ESI-ion trap (IT)-MS.

The focus of our study is on the detailed mass spectrometric characterization of the Flavomycin complex and the identification of novel natural moenomycin compounds by, for the first time, matrix-assisted laser desorption/ionization-ion trap/reflectron time-offlight multistage mass spectrometry (MALDI-IT/ RTOF-MS) and additional LC-ESI-IT-MS. The applicability of the MALDI-IT/RTOF-MS technique to the structural analysis of oligosaccharides and glycopeptides has been described in previous work [33-38] and is extended to the class of medically relevant phosphoglycolipids.

\section{Experimental}

\section{Materials}

Flavomycin was obtained from Hoechst Roussel Vet (Wiesbaden, Germany). The MALDI matrix compound 2,4,6-trihydroxyacetophenone monohydrate (2,4,6THAP) and the additive diammonium hydrogen citrate were obtained from Fluka (Buchs, Switzerland). Ammonium acetate was supplied by Sigma-Aldrich (St. Louis, MO). Sodium chloride, methanol, and water with 
a specific conductivity of $\leq 1 \mu \mathrm{Scm}^{-1}$ were purchased from Merck (Darmstadt, Germany).

\section{MALDI Sample Preparation}

Sample preparation was performed on microtiter format stainless-steel target slides from Shimadzu BiotechKratos Analytical (Manchester, UK). Flavomycin was dissolved in $20 \mathrm{mM}$ aqueous ammonium acetate to 0.1 $\mathrm{gL}^{-1}$. For negative ion mode measurements, $0.4 \mu \mathrm{L}$ of $0.2 \mathrm{M}$ aqueous diammonium hydrogen citrate, $0.6 \mu \mathrm{L}$ of the Flavomycin solution, and $0.8 \mu \mathrm{L}$ of a solution of 20 $\mathrm{gL}^{-1} 2,4,6$-THAP in methanol were mixed on the target in the given order and dried at room temperature in a gentle stream of air. For positive ion mode measurements, either the same preparation method was used or the $0.2 \mathrm{M}$ aqueous diammonium hydrogen citrate was replaced by $20 \mathrm{mM}$ aqueous sodium chloride.

\section{MALDI-IT/RTOF Mass Spectrometry}

The MALDI-MS ${ }^{1}$ and MALDI-low-energy CID-MS ${ }^{n}$ $(n=2-3)$ measurements were performed on an AXIMA-QIT (Shimadzu Biotech-Kratos Analytical). This hybrid-instrument consists of a 3D quadrupole ion trap coupled to a double-stage gridless reflectron TOF analyzer [39, 40]. The AXIMA-QIT is equipped with a pulsed nitrogen laser, having a wavelength of $337 \mathrm{~nm}$ and a pulse width (FWHM) of about $4 \mathrm{~ns}$, and an integrated $1 \mathrm{GHz}$ recorder. The total acceleration voltage in negative and positive ion mode was $\pm 4 \mathrm{kV}$. The ion trap was continuously supplied with helium at a pressure of $5 \times 10^{-5}$ mbar to allow collisional cooling of the trapped ions. In addition, a short pulse of argon was injected into the IT immediately before the ion introduction to enhance the ion-cooling efficiency and immediately before the radio frequencyinduced precursor ion excitation to enhance the fragmentation efficiency during CID in $\mathrm{MS}^{\mathrm{n}}$-mode. CID spectra were acquired by averaging 1024-5041 unselected single laser shots using a precursor ion selection width of $1 / 70,1 / 250$, or $1 / 1000$ of the precursor ion mass in $\mathrm{MS}^{2}$ and $1 / 70$ or $1 / 250$ of the precursor ion mass in $\mathrm{MS}^{3}$. External mass calibration using fullerite (Shimadzu Biotech-Kratos Analytical) or the synthetic peptide $\mathrm{P}_{14} \mathrm{R}$ (Sigma-Aldrich) was performed for mass assignment.

\section{LC-ESI-IT Mass Spectrometry}

The measurements were carried out on an Agilent 1100 HPLC (Agilent Technologies, Waldbronn, Germany) coupled to a ThermoFinnigan LCQ Deca XP ion trap mass spectrometer (ThermoFinnigan, San Jose, CA) fitted with an orthogonal ESI ion source. Chromatographic separation of the Flavomycin constituents was performed with a Hypersil ODS-column of $200 \times 2.1$ $\mathrm{mm}$ dimension having a particle size of $5 \mu \mathrm{m}$ (Thermo Electron, Waltham, MA), and at a column temperature

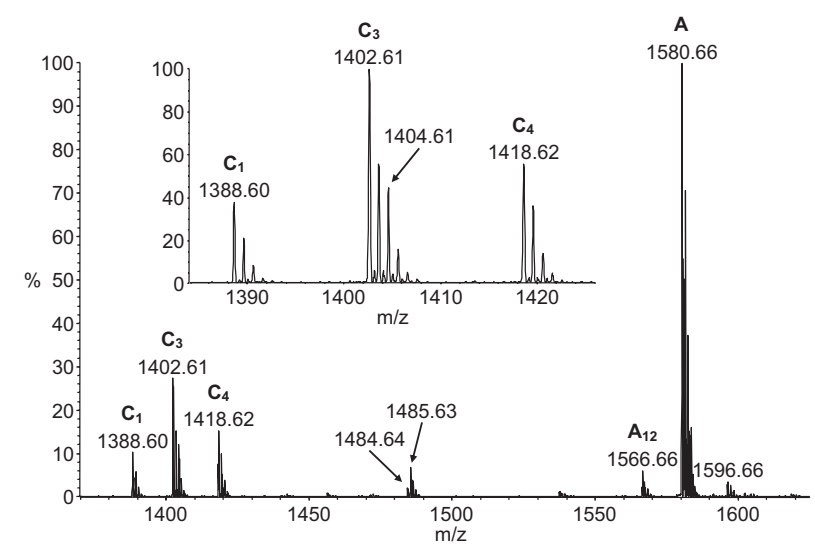

Figure 1. Negative ion mode MALDI-IT/RTOF mass spectrum of the Flavomycin complex showing the $[\mathrm{M}-\mathrm{H}]^{-}$ions of the five known major constituents, namely moenomycin $\mathrm{A}$, moenomycin $\mathrm{A}_{12}$, moenomycin $\mathrm{C}_{4}$, moenomycin $\mathrm{C}_{3}$, and moenomycin $\mathrm{C}_{1}$, and five not yet characterized compounds.

of $50^{\circ} \mathrm{C}$. The solvents used were $10 \mathrm{mM}$ ammonium acetate in doubly distilled water (Solvent A) and $10 \mathrm{mM}$ ammonium acetate in methanol (Solvent B). The gradient was performed from $75-95 \%$ Solvent B for $25 \mathrm{~min}$ at a flow rate of $250 \mu \mathrm{Lmin}^{-1}$. The ESI source was operated in negative ion mode with a source temperature of $200{ }^{\circ} \mathrm{C}$ and a spray voltage of $4 \mathrm{kV}$. The instrument was tuned for maximum transmission of doubly-charged negative ions $\left([\mathrm{M}-2 \mathrm{H}]^{2-}\right)$ and the scan-range was set to $m / z 300-1650$.

\section{Results and Discussion}

\section{MALDI-IT/RTOF-MS ${ }^{1}$}

Positive ion mode MALDI mass spectra of the Flavomycin complex turned out to be of limited use for the characterization of the individual constituents. In contrast to ESI measurements, $[\mathrm{M}+\mathrm{H}]^{+}$ions could not be observed with MALDI, which is related to their low stability [6]. Series of alkali adduct ions ranging from $[\mathrm{M}+\mathrm{Na}]^{+}$up to $[\mathrm{M}+2 \mathrm{Na}+2 \mathrm{~K}-$ $3 \mathrm{H}]^{+}$were detected instead, which resulted in a complicated peak pattern and the overlapping of the isotopic distributions of ions from different compounds. The addition of small amounts of sodium chloride ( $20 \mathrm{mM}$ aqueous sodium chloride was added instead of the $0.2 \mathrm{M}$ aqueous diammonium hydrogen citrate) to suppress potassium adduct ion formation did not improve the situation sufficiently. However, it has to be mentioned that $\mathrm{MS}^{\mathrm{n}}$ experiments of the $[\mathrm{M}$ $+2 \mathrm{Na}-\mathrm{H}]^{+}$ion of moenomycin $\mathrm{A}$, which was the most abundant species, have yielded a large variety of highly abundant fragment ions that would in principle facilitate the structural characterization of this class of compounds (data not shown).

Negative ion mode MALDI measurements using the matrix substance 2,4,6-THAP and diammonium hydrogen citrate as additive (to suppress alkali ad- 

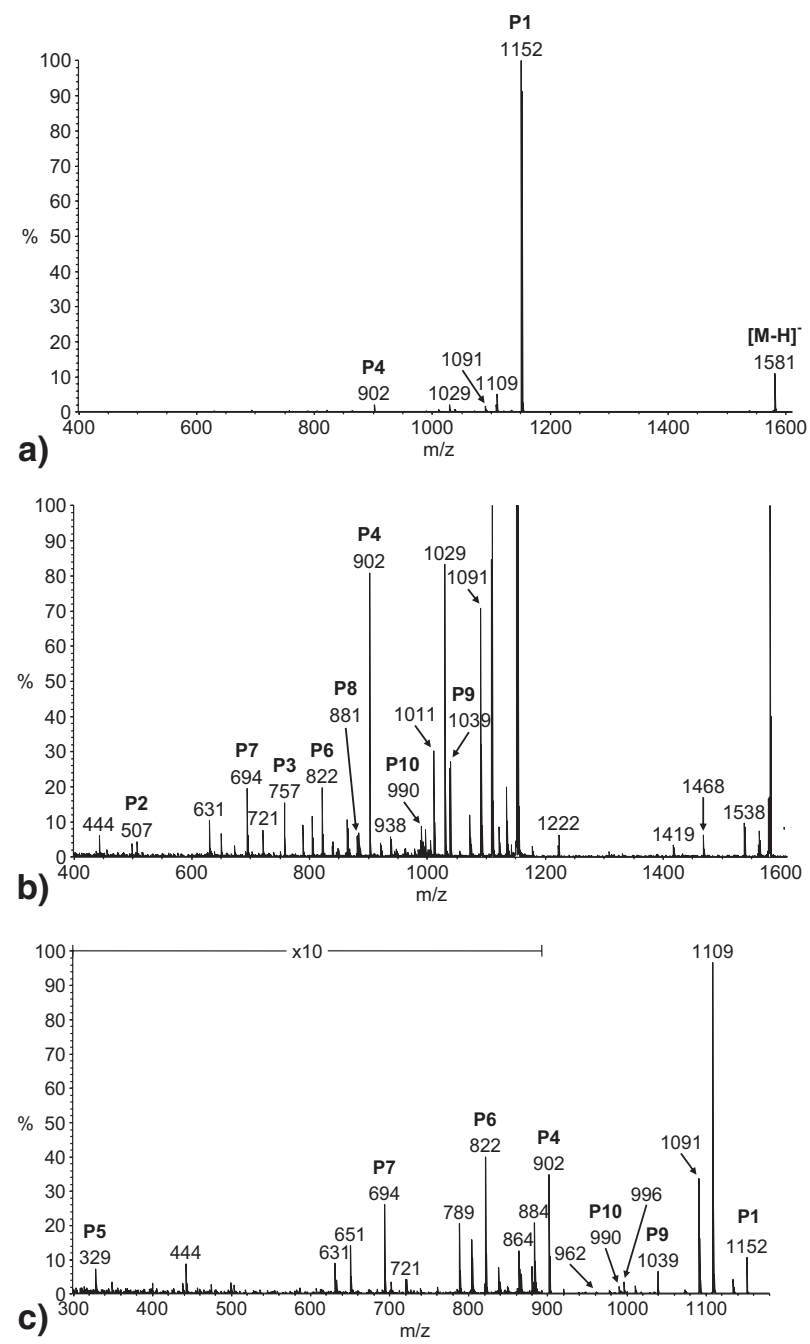

Figure 2. Negative ion mode MALDI-IT/RTOF product ion spectra of moenomycin A: (a) $\mathrm{MS}^{2}$ spectrum of the $[\mathrm{M}-\mathrm{H}]^{-}$ion $(\mathrm{m} / \mathrm{z} 1581 \rightarrow)$; $(\mathbf{b})$ same spectrum amplified by a factor of 42 to show the low abundant product ions; (c) $\mathrm{MS}^{3}$ spectrum of the main product ion $(\mathrm{m} / \mathrm{z} 1581 \rightarrow 1152 \rightarrow)$.

duct ion formation), on the other hand, gave rather clean mass spectra showing nearly exclusively [M $\mathrm{H}]^{-}$ions (Figure 1). Beside the $[\mathrm{M}-\mathrm{H}]^{-}$ions of the five known major components of the Flavomycin complex, several other ions were detected, e.g., at $\mathrm{m} / \mathrm{z}$ 1404.61, $\mathrm{m} / \mathrm{z} 1484.64, \mathrm{~m} / \mathrm{z} 1485.63$, and $\mathrm{m} / \mathrm{z}$ 1596.66. A consequence of the coupling of vacuum MALDI with an ion trap device is the enhanced probability of post source decay in the larger time frame inherent to the trapping process, resulting in the occasionally observed fragmentation of the precursor ions already in $\operatorname{MS}^{1}[33,41]$. Indeed, the rather labile phosphoglycolipids exhibited prompt decay in $\mathrm{MS}^{1}$ as well (most abundant fragment ion/deprotonated molecular ion ratio of approximately $2 / 1$ ). However, in the case of the moenomycins, all abundant fragment ions were below $\mathrm{m} / \mathrm{z} 1200$ and, thus, did not interfere with the analysis of the intact species.

\section{Moenomycin A}

Moenomycin A [21], the main constituent of the Flavomycin complex $(40-80 \%)$, contains a pentasaccharide core (B, C, D, E, F) with a glucopyranosyl residue (D) that is $\beta(1 \rightarrow 6)$-linked to the 2-(acetylamino)-2-deoxyglucopyranosyl group (E) (Scheme 1). The corresponding $[\mathrm{M}-\mathrm{H}]^{-}$ion was detected at $\mathrm{m} / \mathrm{z} 1580.66$ (calc. $\mathrm{m} / \mathrm{z}$ 1580.65) representing the most abundant species (Figure 1). The low-energy CID spectrum of the precursor ion $\mathrm{m} / \mathrm{z} 1581$ shows one predominant product ion at $\mathrm{m} / \mathrm{z}$ 1152 representing the loss of the moenocinol group (I) and the 2,3-dihydroxypropanoic acid group (H) (Figure $2 \mathrm{a}$ and Scheme 2). In addition, only four other ions were detected with a relative intensity $>1 \%$ of the base beak. These ions have all lost the units $\mathbf{H}$ and $\mathbf{I}$, and, in addition, a $\mathrm{HN}=\mathrm{C}=\mathrm{O}$ group $(\mathrm{m} / \mathrm{z} 1109)$, the carbamate group $\left(\mathrm{NH}_{2} \mathrm{COOH}\right)$ from unit $\mathbf{F}(m / z 1091)$, a $\mathrm{HN}=\mathrm{C}=\mathrm{O}$ as well as the $\mathrm{PO}_{3} \mathrm{H}$ group $(\mathrm{m} / \mathrm{z}$ 1029), or the whole uronamide-derived unit $\mathbf{F}(\mathrm{m} / \mathrm{z}$ 902). The formation of the latter ion by an internal residue loss requires a rearrangement reaction, which has been described for several compounds [42-46]. One possible structure of the ion at $m / z$ 902, which is an alternative to the one proposed by Eichhorn and Aga [6], is given in Scheme 2. Most of the interesting product ions in $\mathrm{MS}^{2}$ were

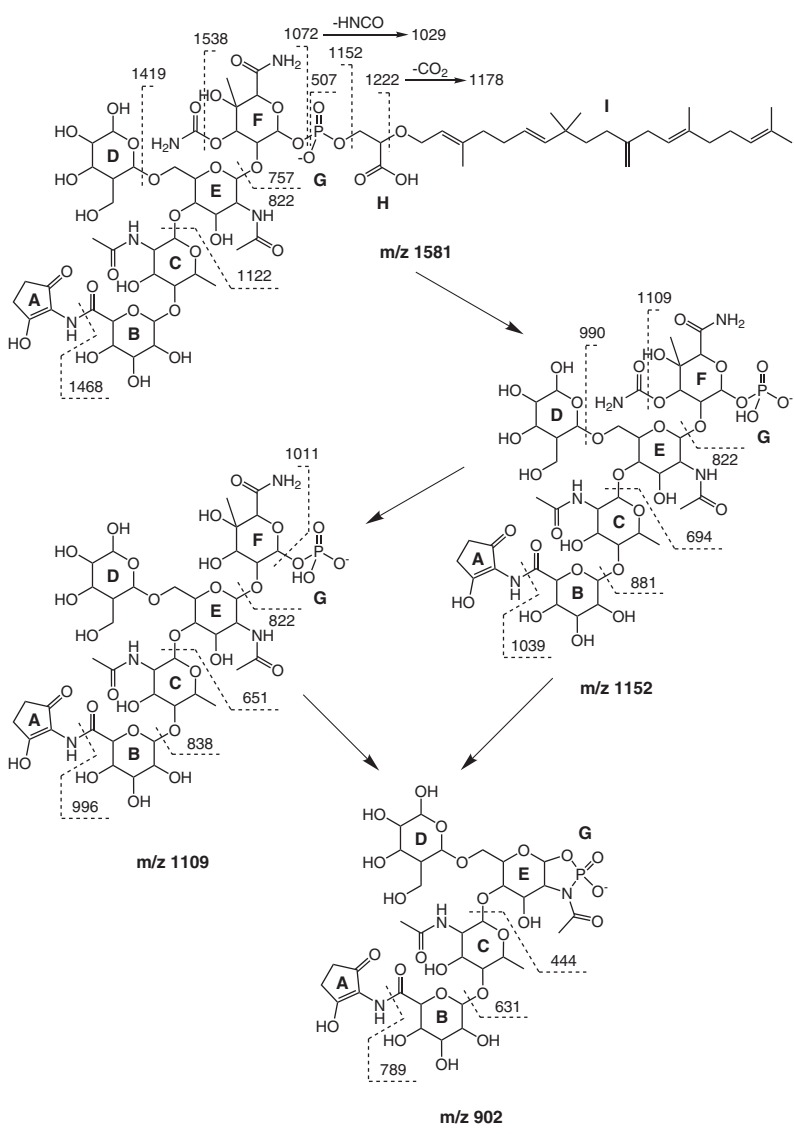

Scheme 2. Proposed low-energy CID fragmentation pathway for the $[\mathrm{M}-\mathrm{H}]^{-}$ion of moenomycin A $\left(\mathrm{MS}^{2} ; \mathrm{m} / z 1581 \rightarrow\right)$. Additional water and ammonia losses have been omitted. 


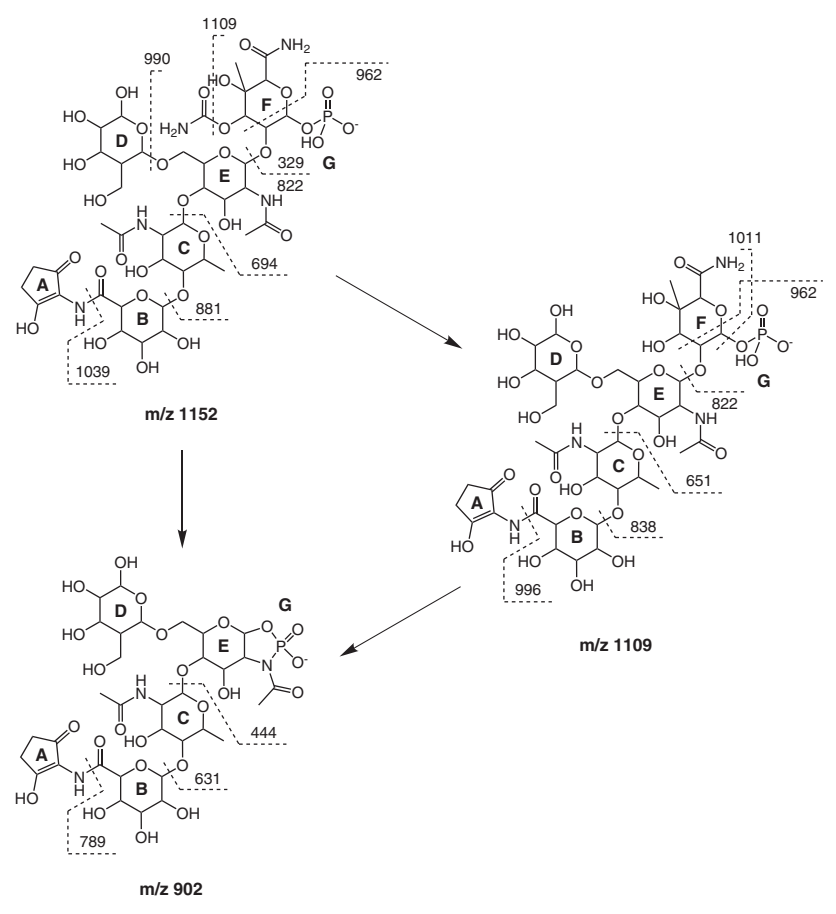

Scheme 3. Proposed low-energy CID fragmentation pathway for the main product ion of moenomycin $\mathrm{A}\left(\mathrm{MS}^{3} ; m / z 1581 \rightarrow 1152 \rightarrow\right)$. Additional water and ammonia losses have been omitted.

observed in the intensity-range below $1 \%$ of the base peak, but still with a good $\mathrm{S} / \mathrm{N}$ ratio (Figure $2 \mathrm{~b}$ and Scheme 2). The $\mathrm{MS}^{3}$-spectrum of the main product ion at $m / z 1152$ showed mainly the same ions that were already present in $\mathrm{MS}^{2}$, with the exception of a product ion at $m / z$ 962, which is assumed to originate from a ${ }^{0,2} \mathrm{X}$-type cross-ring cleavage of unit $\mathbf{F}$, and a low mass product ion at $m / z 329$, assigned to the phosphorylated unit F (Figure 2c and Scheme 3 ). The proposed fragmentation pathways given in Scheme $\mathbf{2}$ and Scheme $\mathbf{3}$ have been corroborated by additional $\mathrm{MS}^{3}$ experiments of the precursor ions at $\mathrm{m} / \mathrm{z} 1109, \mathrm{~m} / \mathrm{z} 1091, \mathrm{~m} / \mathrm{z} 1029$, and $m / z 902$ (data not shown).

From the whole variety of observed fragmentations, ten characteristic product ions have been selected that allow the mass determination of each individual building unit of the moenomycin antibiotics (Scheme 4 and Table 1). The discussion of the CID-behavior of the other compounds of the Flavomycin complex is mainly restricted to these selected product ions to reduce redundancy.

\section{Moenomycin $A_{12}$}

Moenomycin $\mathrm{A}_{12}$ [22] also contains the pentasaccharide core with the glucopyranosyl residue (D), but in contrast to moenomycin $\mathrm{A}$, the 4-C-methyl group in the uronamide-derived unit $\mathbf{F}$ is absent (Scheme 1). The corresponding $[\mathrm{M}-\mathrm{H}]^{-}$ion was detected with low abundance at $m / z 1566.66$ (calc. $m / z$ 1566.64) (Figure 1). The CID-behavior observed in $\mathrm{MS}^{2}$ and in $\mathrm{MS}^{3}$ of the main product ion $\mathbf{P 1}(\mathrm{m} / \mathrm{z} 1138)$ was very similar com- pared to moenomycin A. All product ions containing the unit F (P1, P3, P7, P8, P9, and P10; P5 was only observed with $\mathrm{S} / N<3$ ), were detected at $-14 \mathrm{Da}$, whereas P4 and P6 had identical masses compared to moenomycin A (Table 1). However, the influence of the 4-C-methyl group or, more probably, of the different configuration of unit $\mathbf{F}$ (D-galacto rather than D-gluco) [31], was apparent from significantly increased relative intensities of those product ions originating from the cleavage of bonds around unit $\mathbf{F}$, such as product ions of the type $\mathbf{P} 1-\mathrm{HN}=\mathrm{C}=\mathrm{O}, \mathbf{P} \mathbf{1}-\mathrm{NH}_{2} \mathrm{COOH}$, and $\mathbf{P 6}$ (but not P4).

\section{Moenomycin $C_{4}, C_{3}$, and $C_{1}$}

In moenomycin $C_{4}$ [23], the glucopyranosyl residue (D) is absent, whereas the remaining structure is identical to moenomycin A. Moenomycin $\mathrm{C}_{3}$ [23] and moenomycin $\mathrm{C}_{1}$ [24] both contain a 2-(acetylamino)-2,6-dideoxyglucopyranosyl group as unit $\mathbf{E}$ and moenomycin $\mathrm{C}_{1}$ furthermore lacks the 4-C-methyl group in unit $\mathbf{F}$ (Scheme 1). The corresponding $[\mathrm{M}-\mathrm{H}]^{-}$ions were detected at $m / z 1418.62$ (calc. $m / z$ 1418.60), 1402.61 (calc. $m / z$ 1402.61), and 1388.60 (calc. $m / z$ 1388.59), respectively (Figure 1). The CID behavior observed in $\mathrm{MS}^{2}$ and in $\mathrm{MS}^{3}$ was in all three cases very similar to moenomycin A, although the main product ions (P1) were not that much predominant in $\mathrm{MS}^{2}$. Moenomycin $\mathrm{C}_{4}$ and moenomycin $\mathrm{C}_{3}$ yielded product ions P2, P3, and $\mathbf{P} 5$ with identical masses compared to moenomycin A. All other product ions contain the unit $\mathbf{E}$ and were

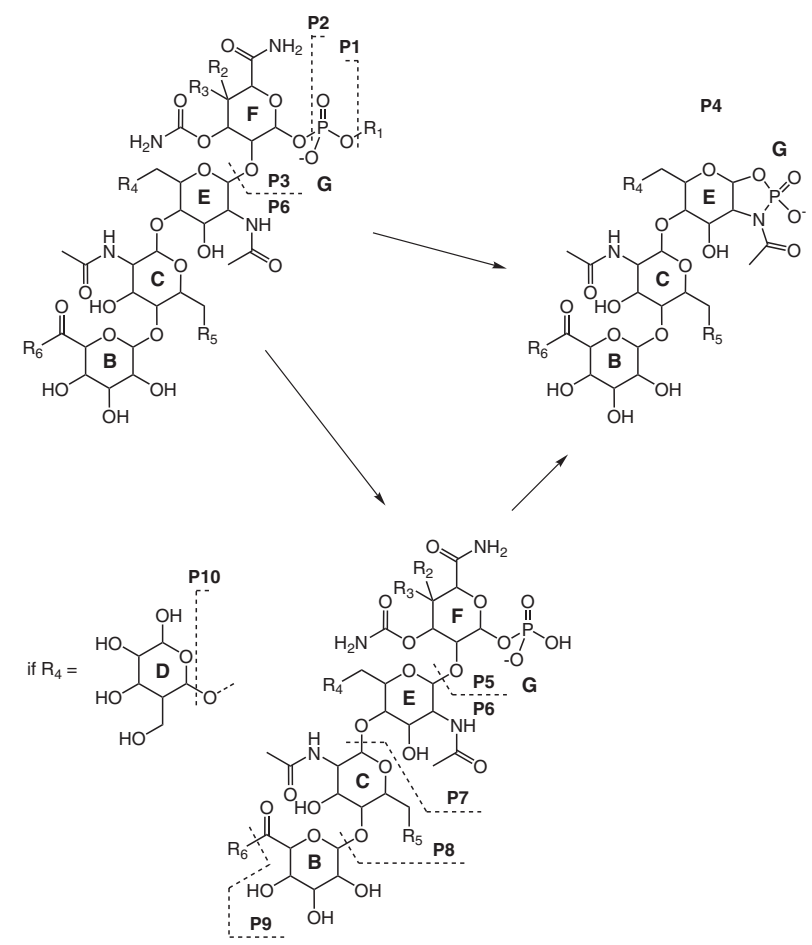

Scheme 4. Ten selected key product ions of moenomycin-type structures. 
Table 1. Observed monoisotopic $\mathrm{m} / \mathrm{z}$-values for the $[\mathrm{M}-\mathrm{H}]^{-}$ions and selected low-energy CID product ions (defined in Scheme 4) of the moenomycin antibiotics

\begin{tabular}{|c|c|c|c|c|c|c|c|c|c|c|c|}
\hline \multirow[b]{2}{*}{ Compound } & \multicolumn{11}{|c|}{$m / z$} \\
\hline & {$[\mathrm{M}-\mathrm{H}]^{-}$} & $\mathrm{P} 1$ & $\mathrm{P} 2$ & P3 & P4 & P5 & P6 & P7 & P8 & P9 & P10 \\
\hline Moenomycin A & 1580.66 & 1152 & 507 & 757 & 902 & 329 & 822 & 694 & 881 & 1039 & 990 \\
\hline Moenomycin $A_{12}$ & 1566.66 & 1138 & n.d. & 743 & 902 & n.d. & 822 & 680 & 867 & 1025 & 976 \\
\hline Moenomycin $\mathrm{C}_{4}$ & 1418.62 & 990 & 507 & 757 & 740 & 329 & 660 & 532 & 719 & 877 & - \\
\hline Moenomycin $C_{3}$ & 1402.61 & 974 & 507 & 757 & 724 & 329 & 644 & 516 & 703 & 861 & - \\
\hline Moenomycin $C_{1}$ & 1388.60 & 960 & 507 & 743 & 724 & 315 & 644 & 502 & 689 & 847 & - \\
\hline$m / z 1405$ & 1404.61 & 976 & n.d. & 743 & 740 & n.d. & 660 & n.d. & 705 & 863 & - \\
\hline$m / z 1485$ & 1484.64 & 1056 & 507 & 757 & 806 & 329 & 726 & 694 & 881 & - & n.d. \\
\hline$m / z 1486$ & 1485.63 & 1057 & 507 & 757 & 807 & 329 & 727 & 694 & 881 & - & 895 \\
\hline$m / z$ 1597a & 1596.66 & 1168 & n.d. & 757 & 918 & n.d. & 838 & 694 & 897 & 1055 & 1006 \\
\hline$m / z$ 1597b & 1596.66 & 1152 & n.d. & n.d. & 902 & n.d. & 822 & 694 & n.d. & 1039 & n.d. \\
\hline
\end{tabular}

n.d., not detected; -, not possible.

therefore detected at $-162 \mathrm{Da}\left(-\mathrm{C}_{6} \mathrm{H}_{10} \mathrm{O}_{5}\right)$ and $-178 \mathrm{Da}$ $\left(-\mathrm{C}_{6} \mathrm{H}_{10} \mathrm{O}_{6}\right)$, respectively (Figure $3 \mathrm{a}$ and Table 1$)$. Those product ions of moenomycin $\mathrm{C}_{1}$ containing unit $\mathrm{F}$ (P3 and P5) were shifted by $-14 \mathrm{Da}$ due to the missing 4-C-methyl group, those containing unit E (P4 and P6) were observed at $-178 \mathrm{Da}$, and those possessing both units (P1, P7, P8, and P9) were detected at $-192 \mathrm{Da}$ (Figure $3 \mathrm{~b}$ and Table 1 ). The product ions $\mathrm{P} 1-\mathrm{HN}=\mathrm{C}=\mathrm{O}$, P1- $\mathrm{NH}_{2} \mathrm{COOH}$ and $\mathbf{P 6}$ were found with higher relative intensity in moenomycin $\mathrm{C}_{1}$ compared to moenomycin $\mathrm{C}_{3}$, showing again the effect of the different configuration of unit F. The product ion P4, on the other hand, was observed to be much less prominent in moenomycin $C_{1}$ and $C_{3}$ compared to the other three moenomycins, indicating that the oxygen at position 6 of unit $\mathbf{E}$ favors the rearrangement reaction that causes the internal loss of unit $\mathbf{F}$.

\section{F-Demethyl-6E-O-de- $\beta$-D-Glucopyranosyl- Moenomycin A}

The measured isotopic pattern of moenomycin $C_{3}$ has been found to strongly differ from the theoretical distribution, which could only be explained by the presence of a second component, whose monoisotopic peak overlaps with the third isotopic peak of moenomycin $\mathrm{C}_{3}$ at $m / z 1404.61$ (Figure 1). Indeed, product ions not related to moenomycin $\mathrm{C}_{3}$ were observed in $\mathrm{MS}^{2}$ and $\mathrm{MS}^{3}$ spectra obtained with a precursor ion selection width in $\mathrm{MS}^{2}$ of $1 / 250$ of the precursor ion mass, corresponding to 5.6 Th (data not shown). These product ions disappeared when the precursor ion selection width had been reduced to $1 / 1000$ of the precursor ion mass (corresponding to $1.4 \mathrm{Th}$ ), which is feasible with the applied instrument at the expense of sensitivity, so that only the first two isotopes of moenomycin $\mathrm{C}_{3}$ were isolated (Figure 3a). The relative abundance of these product ions was, on the other hand, strongly enhanced when only the isotopes at 1405.60 and 1406.58 were isolated and fragmented (Figure 3c). This way, several product ions belonging to the component at $\mathrm{m} / \mathrm{z} 1404.61$
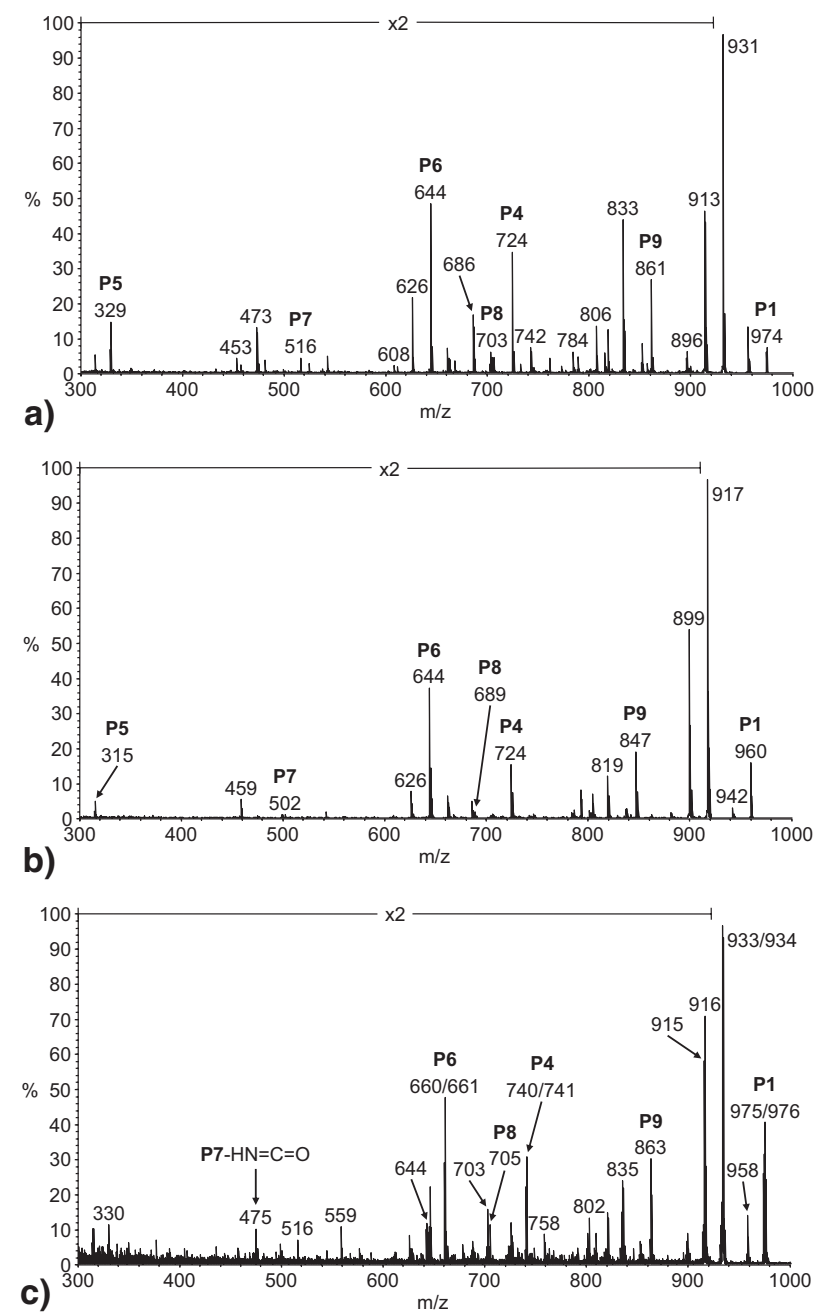

Figure 3. Negative ion mode MALDI-IT/RTOF product ion spectra $\left(\mathrm{MS}^{3}\right)$ of $(\mathbf{a})$ moenomycin $\mathrm{C}_{3}(\mathrm{~m} / z 1403 \rightarrow 974 \rightarrow)$; (b) moenomycin $C_{1}(m / z 1389 \rightarrow 960 \rightarrow)$; $($ c) the new compound assigned as $4 \mathrm{~F}$-demethyl-6E-O-de- $\beta$-D-glucopyranosyl-moenomycin A $(m / z 1405 \rightarrow 976 \rightarrow)$. The latter spectrum $(\mathbf{c})$ was obtained from the second and third isotopes of 4F-demethyl-6E-O-de- $\beta$-Dglucopyranosyl-moenomycin $\mathrm{A}$, but also contains product ions derived from the fourth and fifth isotopes of moenomycin $C_{3}$. 


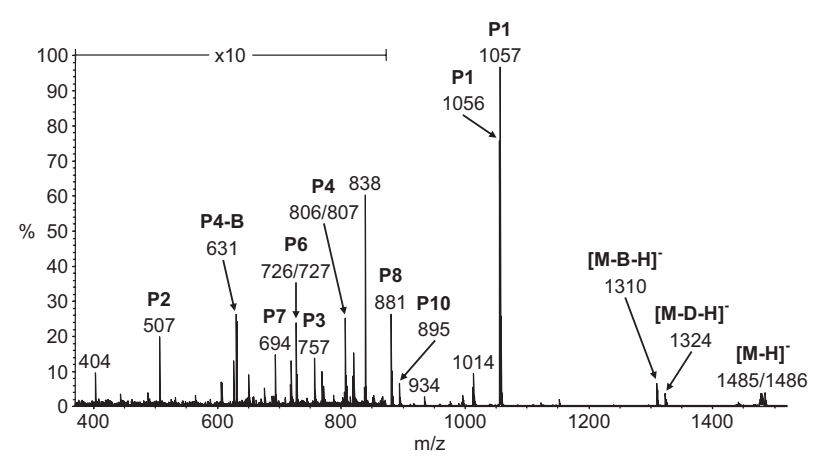

Figure 4. Mixed negative ion mode MALDI-IT/RTOF product ion spectrum $\left(\mathrm{MS}^{2}\right)$ of the new compounds assigned as $6 \mathrm{~B}-\mathrm{N}-$ de(2-hydroxy-5-oxo-1-cyclopenten-1-yl)-moenomycin A and 6Bhydroxy-6B-de[N-(2-hydroxy-5-oxo-1-cyclopenten-1-yl)amino]moenomycin A $(\mathrm{m} / \mathrm{z} 1485 / 1486 \rightarrow)$.

could be unambiguously assigned, although CID spectra of the pure compound were not obtained. The product ions P1, P8, and P9 were detected at $+2 \mathrm{Da}$ compared to moenomycin $C_{3}$, indicating that groups $\mathbf{A}$, $\mathbf{B}, \mathbf{H}$, and I are identical. P3 was found at $\mathrm{m} / \mathrm{z} 743$ instead of $m / z 757$, which points out the absence of the 4-C-methyl group in unit $\mathbf{F}$, such as in the case of moenomycin $\mathrm{A}_{12}$ and moenomycin $\mathrm{C}_{1}$. Consequently, P4 and P6 had a mass shift of +16 Da compared to moenomycin $C_{3}$ (Figure $3 c$ and Table 1). Although P7 could not be detected with a sufficient S/N-ratio, the product ion $\mathrm{P} 7-\mathrm{HN}=\mathrm{C}=\mathrm{O}$ was observed at $\mathrm{m} / \mathrm{z} 475$, which allows the localization of the additional oxygen at unit E. This lets us assume the presence of the 2-(acetylamino)-2-deoxyglucopyranosyl group as unit E, such as in the case of moenomycin $\mathrm{C}_{4}$. Thus, the new compound at $m / z 1404.61$ is assigned as $4 \mathrm{~F}$-demethyl$6 \mathrm{E}-\mathrm{O}-\mathrm{de}-\beta$-D-glucopyranosyl-moenomycin A. This compound is a very likely (by)product of the moenomycin biosynthesis considering the known variability of both, the 4-C-methyl group in unit $\mathrm{F}$ and the 6-hydroxy group in unit $\mathbf{E}$.

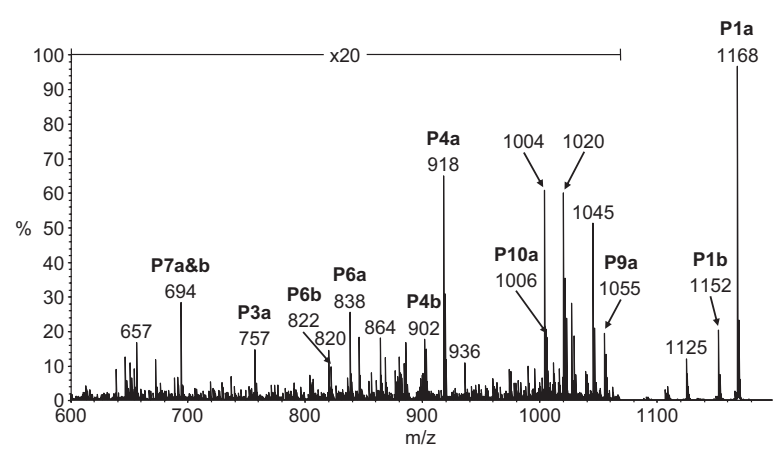

Figure 5. Mixed negative ion mode MALDI-IT/RTOF product ion spectrum $\left(\mathrm{MS}^{2}\right)$ of the two new isobaric compounds assigned as 6C-hydroxy-moenomycin A (product ions labeled Pxa) and oxidized moenomycin A (product ions labeled Pxb) $(m / z 1597 \rightarrow$ ). Only the $m / z$-range $600-1200$ is shown.

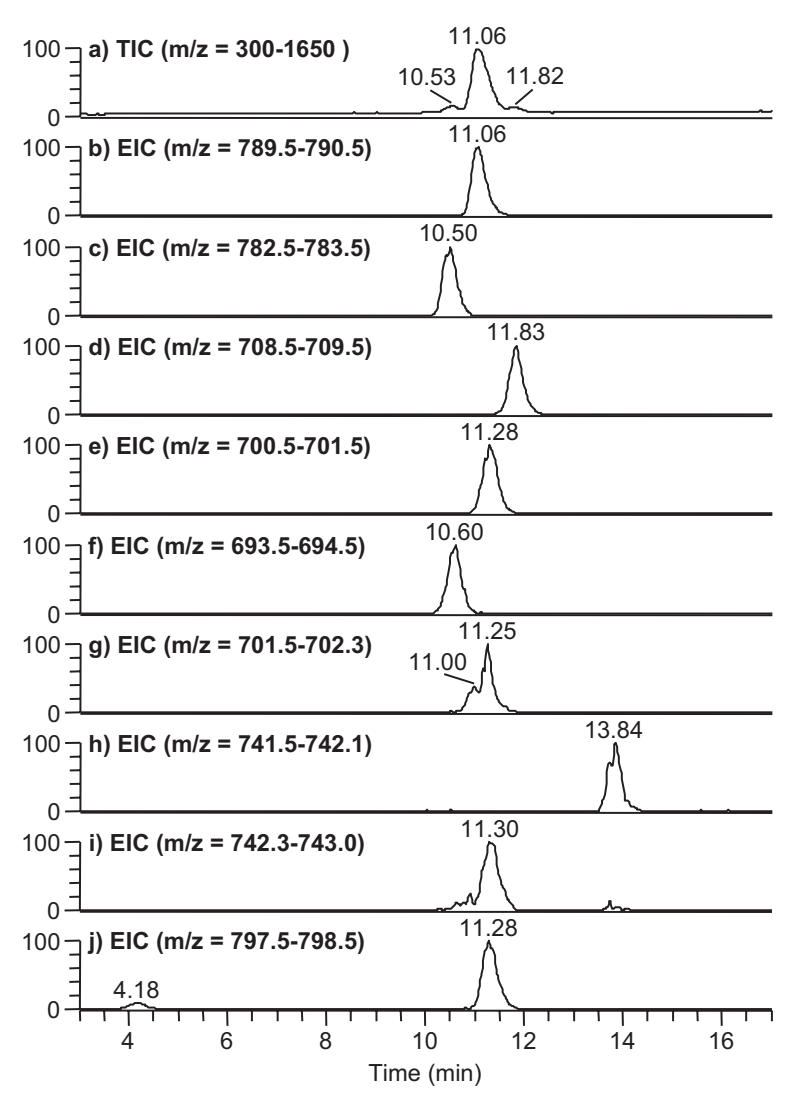

Figure 6. Negative ion mode LC-ESI-IT-MS (a) total ion chromatogram (TIC) of the Flavomycin complex and (b)-(j) extracted ion chromatograms $(\mathrm{EIC})$ of the $[\mathrm{M}-2 \mathrm{H}]^{2-}$ ions of the 10 analyzed constituents. The displayed $m / z$-traces correspond to (b) moenomycin $\mathrm{A}$, (c) moenomycin $\mathrm{A}_{12}$, (d) moenomycin $\mathrm{C}_{4}$, (e) moenomycin $\mathrm{C}_{3}$, (f) moenomycin $\mathrm{C}_{1}$, (g) $4 \mathrm{~F}$-demethyl-6E-O-de- $\beta$ D-glucopyranosyl-moenomycin A (RT $11.00 \mathrm{~min}$ ), and moenomycin $\mathrm{C}_{3}(\mathrm{RT}=11.25 \mathrm{~min})$, (h) 6B-N-de(2-hydroxy-5-oxo-1cyclopenten-1-yl)-moenomycin A, (i) 6B-hydroxy-6B-de[N-(2hydroxy-5-oxo-1-cyclopenten-1-yl)amino]-moenomycin $\mathrm{A}$, and (j) 6C-hydroxy-moenomycin A $(\mathrm{RT}=11.28 \mathrm{~min})$ and oxidized moenomycin $\mathrm{A}(\mathrm{RT}=4.18 \mathrm{~min})$.

6B-N-de(2-Hydroxy-5-oxo-1-Cyclopenten-1-yl)Moenomycin $A$ and 6B-Hydroxy-6B-de[N-(2Hydroxy-5-oxo-1-Cyclopenten-1-yl)Amino]Moenomycin $A$

Two other novel components of the Flavomycin complex were detected at 1484.64 Da and 1485.63 Da (Figure 1). Due to the strong overlap of the isotopic patterns, both components have been isolated and subjected to CID experiments at once (Figure 4). They yielded product ions of the type P2, P3, P5, P7, and P8 that had identical masses compared to moenomycin A. Only product ions containing the unit $\mathbf{B}$, namely $\mathbf{P 1}, \mathbf{P 4}$, and P6, where detected at $-96 \mathrm{Da}$ and $-95 \mathrm{Da}$ (Table 1). From these results, it was concluded that the new compounds are moenomycin A-like structures that lack the chromophore unit A. In the less abundant compound at $m / z 1484.64 \mathrm{Da}$, unit B remains as a galactopyranuronamid. This 6B-N-de(2-hydroxy-5-oxo-1-cyclopenten-1-yl)-moenomycin A has been previously 


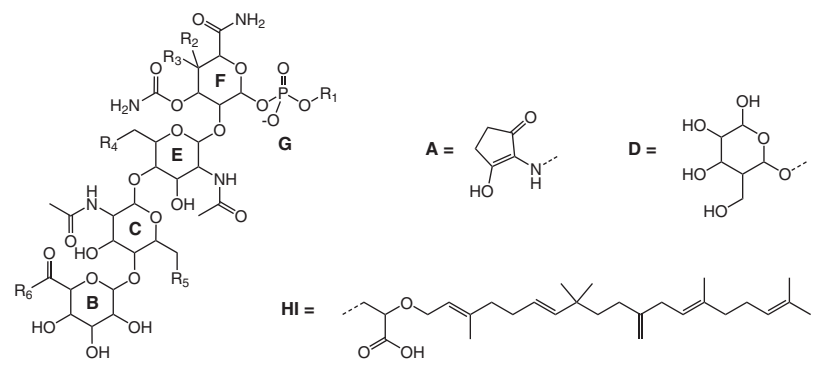

Scheme 5. Structure of the ten characterized moenomycin antibiotics that constitute the Flavomycin complex. The nature of the six variable positions $\left(R_{1}-R_{6}\right)$ is given in Table 2 .

synthesized by $\mathrm{K}_{3}\left[\mathrm{Fe}(\mathrm{CN})_{6}\right]$ oxidation of moenomycin $\mathrm{A}$ and was shown to be antibiotically active [47]. In the compound at $m / z 1485.63 \mathrm{Da}$, unit $\mathbf{B}$ is assumed to be converted to a galactopyranuronic acid. Although the fragmentation pathway of these compounds is still nearly identical compared to moenomycin A, the missing 2-hydroxy-5-oxo-1-cyclopenten-1-yl-group has a strong effect on the relative intensities of some product ions (Figure 4). The most prominent effect was observed for $\mathbf{P 8}$ and other product ions originating from the loss of unit B (e.g., P4 - B at $m / z 631$ and $[\mathbf{M}-\mathbf{B}-\mathbf{H}]^{-}$at $\mathrm{m} / \mathrm{z}$ 1310), which were detected with strongly enhanced relative intensities. Surprisingly, the presence of the terminal galactopyranuronic acid, but not the galactopyranuronamid group, had also a strong favoring effect toward the loss of unit $\mathbf{D}$, which can be seen for P10 or the loss of unit $\mathbf{D}$ from the intact molecule ([M - D $\mathrm{H}]^{-}$at $m / z$ 1324).

The presence of the two moenomycin A-like compounds lacking the chromophore unit $\mathbf{A}$, which might either originate from an incomplete biosynthesis or from a degradation of the mature moenomycin A, suggests the presence of the corresponding compounds from the other known moenomycins as well. Indeed, very small peaks could be found at $-96 /-95 \mathrm{Da}$ of moenomycin $A_{12}$, moenomycin $C_{4}$, moenomycin $C_{3}$, and moenomycin $\mathrm{C}_{1}$ in $\mathrm{MS}^{1}$, but the abundance of these ions was too low to obtain useful $\mathrm{MS}^{2}$ spectra.

\section{C-Hydroxy-Moenomycin A and Oxidized Moenomycin A}

Two other novel, isobaric compounds of the Flavomycin complex were discovered at 1596.66 Da (Figure 1). The more abundant of these two constituents yielded only two product ions with identical masses compared to moenomycin A, namely $\mathbf{P} 3$ and $\mathbf{P 7}$, which contain the units D-I (P2 and P5 were not detected with sufficient S/N). All other product ions, including $\mathbf{P 9}$ and $\mathbf{P 8}$, had a mass shift of +16 Da compared to moenomycin A (see Figure 5 and $m / z$ 1597a in Table 1), which means that units $\mathbf{A}$ and $\mathbf{B}$ also have the same mass as in moenomycin A. Consequently, unit $\mathbf{C}$ must carry a modification that causes the observed mass shift of $+16 \mathrm{Da}$. This finding is also corroborated by a number of other product ions, such as the one originating from further fragmentation of P4 (analogous to Scheme 2). Although a more exact localization was not possible from the observed low-energy CID product ions, we assume that the unit $\mathbf{C}$ in this component carries a hydroxy-group in position 6 . The presence of 6C-hydroxy-moenomycin $\mathrm{A}$ in the Flavomycin complex is also not completely surprising, taking into account the similarity of unit $\mathbf{C}$ to unit $\mathrm{E}$, and the presence of a 2-(acetylamino)-2deoxyglucopyranosyl group as unit $\mathbf{C}$ in the moenomycin-type antibiotics pholipomycin (6E-O-de- $\beta$-Dglucopyranosyl-6C-hydroxy-moenomycin A) from Streptomyces lividoclavatus [23, 29] and AC326- $\alpha$ from Actinomyces AC326 [30]. The latter is structurally identical to the proposed 6C-hydroxy-moenomycin A except that it possesses a cyclized moenocinol derivative.

The second compound at $\mathrm{m} / \mathrm{z} 1596.66$ Da yielded a series of product ions in $\mathrm{MS}^{2}$, namely P1, P4, P6, and P9, which cannot originate from 6C-hydroxy-moenomycin A but are identical to moenomycin A (see Figure 5 and $\mathrm{m} / \mathrm{z} 1597 \mathrm{~b}$ in Table 1 ). These product ions clearly show that the units A-G have the same mass as in moenomycin A and, although $\mathbf{P} 2$ and $\mathbf{P} 3$ could not be detected due to the low abundance of this constituent, suggest that unit $\mathbf{H}$ or $\mathbf{I}$ are modified to give a mass shift of +16 Da. We assume that this compound is a chemical

Table 2. The nature of the six variable positions $\left(R_{1}-R_{6}\right.$ in Scheme 5) in the structure of the ten characterized moenomycin antibiotics that constitute the Flavomycin complex

\begin{tabular}{|c|c|c|c|c|c|c|}
\hline Compound & $\mathrm{R}_{1}$ & $\mathrm{R}_{2}$ & $\mathrm{R}_{3}$ & $\mathrm{R}_{4}$ & $\mathrm{R}_{5}$ & $\mathrm{R}_{6}$ \\
\hline Moenomycin A & HI & $\mathrm{CH}_{3}$ & $\mathrm{OH}$ & D & $\mathrm{H}$ & A \\
\hline Moenomycin $\mathrm{A}_{12}$ & HI & $\mathrm{OH}$ & $\mathrm{H}$ & D & $\mathrm{H}$ & A \\
\hline Moenomycin $C_{4}$ & HI & $\mathrm{CH}_{3}$ & $\mathrm{OH}$ & $\mathrm{OH}$ & $\mathrm{H}$ & A \\
\hline Moenomycin $C_{3}$ & HI & $\mathrm{CH}_{3}$ & $\mathrm{OH}$ & $\mathrm{H}$ & $\mathrm{H}$ & $A$ \\
\hline Moenomycin $C_{1}$ & HI & $\mathrm{OH}$ & $\mathrm{H}$ & $\mathrm{H}$ & $\mathrm{H}$ & $A$ \\
\hline$m / z 1405$ & HI & $\mathrm{OH}$ & $\mathrm{H}$ & $\mathrm{OH}$ & $\mathrm{H}$ & A \\
\hline$m / z 1485$ & HI & $\mathrm{CH}_{3}$ & $\mathrm{OH}$ & D & $\mathrm{H}$ & $\mathrm{NH}_{2}$ \\
\hline$m / z 1486$ & HI & $\mathrm{CH}_{3}$ & $\mathrm{OH}$ & D & $\mathrm{H}$ & $\mathrm{OH}^{2}$ \\
\hline $\mathrm{m} / \mathrm{z} 1597 \mathrm{a}$ & HI & $\mathrm{CH}_{3}$ & $\mathrm{OH}$ & D & $\mathrm{OH}$ & A \\
\hline$m / z 1597 b$ & oxidized $\mathbf{H I}$ & $\mathrm{CH}_{3}$ & $\mathrm{OH}$ & D & $\mathrm{H}$ & A \\
\hline
\end{tabular}


degradation product of moenomycin A, originating from oxidation of the moenocinol group (I) [48].

\section{LC-ESI-IT Mass Spectrometry}

The negative ion mode LC-ESI-IT-MS total ion chromatogram (TIC) of the Flavomycin complex and the extracted ion chromatograms (EIC) of the $[\mathrm{M}-2 \mathrm{H}]^{2-}$ ions of the 10 analyzed constituents are shown in Figure 6. The different components of the mixture were only partially separated by $\mathrm{C}_{18}$-RP-chromatography under the given conditions. The major component, moenomycin A, eluted at 11.06 min (Figure 6b). Moenomycin $C_{3}$ (Figure 6e, $11.28 \mathrm{~min}$ ), 4F-demethyl-6E-O-de- $\beta$-D-glucopyranosyl-moenomycin A (Figure $6 \mathrm{~g}, \sim 11.00 \mathrm{~min}$ ), 6B-hydroxy-6B-de[N-(2-hydroxy-5-oxo-1-cyclopenten1-yl)amino]-moenomycin A (Figure 6i, $11.30 \mathrm{~min}$ ), and 6C-hydroxy-moenomycin A (Figure 6j, $11.28 \mathrm{~min}$ ) were barely separated from moenomycin $\mathrm{A}$ and from each other. Moenomycin $\mathrm{C}_{4}$ (Figure $6 \mathrm{~d}, 11.83 \mathrm{~min}$ ) and 6B-N-de(2-hydroxy-5-oxo-1-cyclopenten-1-yl)-moenomycin A (Figure 6h, $13.84 \mathrm{~min}$ ) were more strongly retained in the LC column than the above mentioned compounds. Moenomycin $\mathrm{A}_{12}$ (Figure 6c, $10.50 \mathrm{~min}$ ) and moenomycin $C_{1}$ (Figure $6 f, 10.60 \mathrm{~min}$ ) (co)-eluted before moenomycin $\mathrm{A}$ and moenomycin $\mathrm{C}_{3}$, respectively, which was expected due to the missing $4 \mathrm{~F}$ methyl-group. The same effect was observed for $4 \mathrm{~F}-$ demethyl-6E-O-de- $\beta$-D-glucopyranosyl-moenomycin $A$, which eluted before moenomycin $C_{4}$. The low abundant compound eluting at $4.18 \mathrm{~min}$ (Figure 6j) was subjected to $\mathrm{MS}^{2}$ and this experiment confirmed that this peak represents the oxidized moenomycin A. The large reduction in the retention time observed for this compound further corroborates that this constituent possesses a free hydroxy-group in the otherwise hydrophobic isoprenoid-like substructure (unit I). Interestingly, an additional hydroxy-group in the per se polar part of this amphiphilic molecule, either on unit $\mathbf{E}$ (moenomycin $\mathrm{C}_{1}$ versus $4 \mathrm{~F}$-demethyl$6 \mathrm{E}-\mathrm{O}-\mathrm{de}-\beta$-D-glucopyranosyl-moenomycin $\mathrm{A}$ and moenomycin $C_{3}$ versus moenomycin $C_{4}$ ) or on unit $C$ (moenomycin $A$ versus 6C-hydroxy-moenomycin A), causes a stronger retention.

Although not all components could be baselineseparated under the applied conditions, the observed elution order of the constituents of the moenomycin complex on the reversed-phase column might be helpful in future studies aiming on the isolation and further characterization of these structures. The differences in the retention time of the postulated new constituents compared to the known constituents give clear evidence that the corresponding MALDI-generated ions represent true deprotonated molecular ions instead of fragment ions originating from the in- or post-source decay of moenomycins with higher molecular masses.

\section{Conclusions}

Negative ion mode multistage low-energy CID using a MALDI-IT/RTOF-MS, which allows detection of the fragment ions in the last CID stage in the high-resolution mode, and negative ion mode LC-ESI-IT-MS were used for the analysis of the constituents of Flavomycin, which is a mixture of structurally closely related substances. Particularly, the negative ion MALDI-MS mode turned out to be extremely useful for the characterization of the very complex phosphoglycolipids. Based on the derived fragmentation pathway of the $[\mathrm{M}-\mathrm{H}]^{-}$ ions of the five known compounds constituting the Flavomycin complex, namely moenomycin $\mathrm{A}$, moenomycin $A_{12}$, moenomycin $C_{4}$, moenomycin $C_{3}$, and moenomycin $C_{1}$, four not yet described constituents could be characterized (Scheme 5 and Table 2). 4Fdemethyl-6E-O-de- $\beta$-D-glucopyranosyl-moenomycin A and 6C-hydroxy-moenomycin $\mathrm{A}$ are most probably (by)products of the moenomycin biosynthesis. They might be of interest in the elucidation of the enzymatic assembly of this class of compounds. In the case of the two structures lacking the chromophore unit A, namely 6B-N-de(2-hydroxy-5-oxo-1-cyclopenten-1-yl)-moenomycin A and 6B-hydroxy-6B-de[N-(2-hydroxy-5-oxo-1cyclopenten-1-yl)amino]-moenomycin $\mathrm{A}$, it cannot be unambiguously stated whether this compounds are biosynthetic intermediates or degradation products. Chemically derived 6B-N-de(2-hydroxy-5-oxo-1-cyclopenten-1-yl)-moenomycin A has already been shown to be antibiotically active [47]. From structure-activity relationship analysis of the moenomycins $[3,7-9,12,25]$ and the activity of pholipomycin [23, 29] and AC326- $\alpha$ [30] it can be concluded that the other three above mentioned substances are potent antibiotics as well. Furthermore, a moenomycin A carrying an oxygen in the moenocinol-group was found, which is most probably a chemical degradation product. This compound is assumed to have a comparable low, if any, antibiotic activity [48].

\section{Acknowledgments}

The authors thank Emmanuel Raptakis (Shimadzu Biotech-Kratos Analytical, Manchester, UK) for helpful discussions regarding the operation of the first generation MALDI-IT/RTOF-instrument. They gratefully acknowledge financial support by the Austrian Science Foundation (grant P15008 to GA).

\section{References}

1. Wallhaeusser, K. H.; Nesemann, G.; Praeve, P.; Steigler, A. Moenomycin, a New Antibiotic. I. Fermentation and Isolation. Antimicrob. Agents Chemother. 1965, 1965, 734-736.

2. Butaye, P.; Devriese, L. A.; Haesebrouck, F. Antimicrobial Growth Promoters Used in Animal Feed: Effects of Less Well Known Antibiotics on Gram-Positive Bacteria. Clin. Microbiol. Rev. 2003, 16, 175-188.

3. Welzel, P. Syntheses around the Transglycosylation Step in Peptidoglycan Biosynthesis. Chem. Rev. 2005, 105, 4610-4660.

4. von Wasielewski, E.; Muschaweck, R.; Schuetze, E. Meonomycin, a New Antibiotic. III. Biological Properties. Antimicrob. Agents Chemother. 1965, 1965, 743-748.

5. Commission of the European Communities. Update (Situation as of 30 April 2004) of the List of the Authorized Additives in Feeding Stuffs 
Published in Application of Article 9t.b of Council Directive 70/524/EEC Concerning Additives in Feeding Stuffs.

6. Eichhorn, P.; Aga, D. S. Characterization of Moenomycin Antibiotics from Medicated Chicken Feed by Ion-Trap Mass Spectrometry with Electrospray Ionization. Rapid Commun. Mass Spectrom. 2005, 19, 2179 2186.

7. Goldman, R. C.; Gange, D. Inhibition of Transglycosylation Involved in Bacterial Peptidoglycan Synthesis. Curr. Med. Chem. 2000, 7, 801-820.

8. van Heijenoort, J. Formation of the Glycan Chains in the Synthesis of Bacterial Peptidoglycan. Glycobiology 2001, 11, 25R-36R.

9. El-Abadla, N.; Lampilas, M.; Hennig, L.; Findeisen, M.; Welzel, P.; Mueller, D.; Markus, A.; van Heijenoort, J. Moenomycin A: The Role of the Methyl Group in the Moenuronamide Unit and a General Discussion of Structure-Activity Relationships. Tetrahedron 1999, 55, 699-722.

10. Volke, D.; Daghish, M.; Hennig, L.; Findeisen, M.; Giesa, S.; Oehme, R.; Welzel, P.On Penicillin-Binding Protein 1b Affinity-Labeling Reagents. Helv. Chim. Acta 2003, 86, 4214-4232.

11. Paik, J.; Kern, I.; Lurz, R.; Hakenbeck, R. Mutational Analysis of the Streptococcus pneumoniae Bimodular Class A Penicillin-Binding Proteins. J. Bacteriol. 1999, 181, 3852-3856.

12. Stembera, K.; Vogel, S.; Buchynskyy, A.; Ayala, J. A.; Welzel, P. A Surface Plasmon Resonance Analysis of the Interaction Between the Antibiotic Moenomycin A and Penicillin-Binding Protein 1b. ChemBioChem. 2002, 3, 559-565.

13. Baizman, E. R.; Branstrom, A. A.; Longley, C. B.; Allanson, N.; Sofia, M. J.; Gange, D.; Goldman, R. C. Antibacterial Activity of Synthetic Analogues Based on the Disaccharide Structure of Moenomycin, an Inhibitor of Bacterial Transglycosylase. Microbiology 2000, 146, 31293140.

14. Ostash, B.; Walker, S. Bacterial Transglycosylase Inhibitors. Curr. Opin. Chem. Biol. 2005, 9, 459-466.

15. Walsh, C. T.; Wright, G. Introduction: Antibiotic Resistance. Chem. Rev. 2005, 105, 391-394.

16. Fisher, J. F.; Meroueh, S. O.; Mobashery, S. Bacterial Resistance to $\beta$-Lactam Antibiotics: Compelling Opportunism, Compelling Opportunity. Chem. Rev. 2005, 105, 395-424.

17. Magnet, S.; Blanchard, J. S. Molecular Insights into Aminoglycoside Action and Resistance. Chem. Rev. 2005, 105, 477-498.

18. Brown, E. D.; Wright, G. D. New Targets and Screening Approaches in Antimicrobial Drug Discovery. Chem. Rev. 2005, 105, 759-774.

19. Kurz, M.; Guba, W.; Vertesy, L. Three-Dimensional Structure of Moenomycin A-a Potent Inhibitor of Penicillin-Binding Protein 1b. Eur. J. Biochem. 1998, 252, 500-507.

20. Welzel, P.; Wietfeld, B.; Kunisch, F.; Schubert, T.; Hobert, K.; Duddeck, H.; Mueller, D.; Huber, G.; Maggio, J. E.; Williams, D. H. Moenomycin A: Further Structural Studies and Preparation of Simple Derivatives. Tetrahedron 1983, 39, 1583-1591.

21. Fehlhaber, H.-W.; Girg, M.; Seibert, G.; Hobert, K.; Welzel, P.; van Heijenoort, Y.; van Heijenoort, J. Moenomycin A: A Structural Revision and New Structure-Activity Reactions. Tetrahedron 1990, 46, 1557-1568.

22. Donnerstag, A.; Marzian, S.; Mueller, D.; Welzel, P.; Boettger, D.; Staerk, A.; Fehlhaber, H.-W.; Markus, A.; van Heijenoort, Y.; van Heijenoort, J. A Structurally and Biogenetically Interesting Moenomycin Antibiotic. Tetrahedron 1995, 51, 1931-1940.

23. Scherkenbeck, J.; Hiltmann, A.; Hobert, K.; Bankova, W.; Siegels, T.; Kaiser, M.; Mueller, D.; Veith, H. J.; Fehlhaber, H.-W.; Seiberg, G.; Markus, A.; Limbert, M.; Huber, G.; Boettger, D.; Staerk, A.; Takahashi, S.; van Heijenoort, Y.; van Heijenoort, J.; Welzel, P. Structures of Some Moenomycin Antibiotics-Inhibitors of Peptidoglycan Biosynthesis. Tetrahedron 1993, 49, 3091-3100.

24. Hessler-Klintz, M.; Hobert, K.; Biallass, A.; Siegels, T.; Hiegemann, M.; Maulshagen, A.; Mueller, D.; Welzel, P.; Huber, G.; Boettger, D. Markus, A.; Seibert, G.; Staerk, A.; Fehlhaber, H.-W.; van Heijenoort, Y.; van Heijenoort, J. The First Moenomycin Antibiotic without the MethylBranched Uronic Acid Constituent-Unexpected Structure Activity Relations. Tetrahedron 1993, 49, 7667-7678.

25. Welzel, P.; Kunisch, F.; Kruggel, F.; Stein, H.; Scherkenbeck, J.; Hiltmann, A.; Duddeck, H.; Mueller, D.; Maggio, J. E.; Fehlhaber, H.-W.; Seibert, G.; van Heijenoort, Y.; van Heijenoort, J. Moenomycin A: Minimum Structural Requirements for Biological Activity. Tetrahedron 1987, 43, 585-598.

26. Neundorf, I.; Koehler, C.; Hennig, L.; Findeisen, M.; Arigoni, D.; Welzel, $P$. Evidence for the Combined Participation of a $C_{10}$ and a $C_{15}$ Precursor in the Biosynthesis of Moenocinol, the Lipid Part of the Moenomycin Antibiotics. ChemBioChem. 2003, 4, 1201-1205.

27. Anikin, A.; Buchynskyy, A.; Kempin, U.; Stembera, K.; Welzel, P.; Lantzsch, G. Membrane Anchoring and Intervesicle Transfer of a Derivative of the Antibiotic Moenomycin A. Angew. Chem. Int. Ed. Engl. 1999, 38, 3703-3707.

28. Ruehl, T.; Daghish, M.; Buchynskyy, A.; Barche, K.; Volke, D.; Stembera, K.; Kempin, U.; Knoll, D.; Hennig, L.; Findeisen, M.; Oehme, R.; Giesa, S.; Ayala, J.; Welzel, P. Studies on the Interaction of the Antibiotic
Moenomycin A with the Enzyme Penicillin-Binding Protein 1b. Bioorg. Med. Chem. 2003, 11, 2965-2981.

29. Arai, M.; Torikata, A.; Enokita, R.; Fukatsu, H.; Nakayama, R.; Yoshida, K. Pholipomycin, a New Member of Phosphoglycolipid Antibiotics. I. Taxonomy of Producing Organism and Fermentation and Isolation of Pholipomycin. J. Antibiot. 1977, 30, 1049-1054.

30. He, H.; Shen, B.; Korshalla, J.; Siegel, M. M.; Carter, G. T. Isolation and Structural Elucidation of AC326- $\alpha$, a New Member of the Moenomycin Group. J. Antibiot. 2000, 53, 191-195.

31. Hennig, L.; Findeisen, M.; Welzel, P.; Haessner, R. ${ }^{1} \mathrm{H}$ NMR Spectroscopic Studies of the Moenomycins. Magn. Reson. Chem. 1998, 36, 615-620.

32. Subramaniam-Niehaus, B.; Schneider, T.; Metzger, J. W.; Wohlleben, W.Isolation and Analysis of Moenomycin and Its Biosynthetic Intermediates from Streptomyces ghanaensis (ATCC 14672) Wildtype and Selected Mutants. Z. Naturforsch. C. Biosci. 1997, 52, 217-226.

33. Demelbauer, U. M.; Zehl, M.; Plematl, A.; Allmaier, G.; Rizzi, A. Determination of Glycopeptide Structures by Multistage Mass Spectrometry with Low-Energy Collision-Induced Dissociation: Comparison of Electrospray Ionization Quadrupole Ion Trap and Matrix-Assisted Laser Desorption/Ionization Quadrupole Ion Trap Reflectron Time-ofFlight Approaches. Rapid Commun. Mass Spectrom. 2004, 18, 1575-1582.

34. Harvey, D. J.; Martin, R. L.; Jackson, K. A.; Sutton, C. W. Fragmentation of N-Linked Glycans with a Matrix-Assisted Laser Desorption/Ionization Ion Trap Time-of-Flight Mass Spectrometer. Rapid Commun. Mass Spectrom. 2004, 18, 2997-3007.

35. Wada, Y.; Tajiri, M.; Yoshida, S. Hydrophilic Affinity Isolation and MALDI Multiple-Stage Tandem Mass Spectrometry of Glycopeptides for Glycoproteomics. Anal. Chem. 2004, 76, 6560-6565.

36. Harvey, D. J. Structural Determination of N-Linked Glycans by MatrixAssisted Laser Desorption/Ionization and Electrospray Ionization Mass Spectrometry. Proteomics 2005, 5, 1774-1786.

37. Ojima, N.; Masuda, K.; Tanaka, K.; Nishimura, O. Analysis of Neutral Oligosaccharides for Structural Characterization by Matrix-Assisted Laser Desorption/Ionization Quadrupole Ion Trap Time-of-Flight Mass Spectrometry. J. Mass Spectrom. 2005, 40, 380-388.

38. Stübiger, G.; Marchetti, M.; Nagano, M.; Grimm, R.; Gmeiner, G.; Reichel, C.; Allmaier, G. Characterization of N- and O-Glycopeptides of Recombinant Human Erythropoietins as Potential Biomarkers for Doping Analysis by Means of Microscale Sample Purification Combined with MALDI-TOF and Quadrupole IT/RTOF Mass Spectrometry. J. Sep. Sci. 2005, 28, 1764-1778.

39. Ding, L.; Kawatoh, E.; Tanaka, K.; Smith, A. J.; Kumashiro, S. HighEfficiency MALDI-QIT-TOF Mass Spectrometer. Proceedings of SPIEThe International Society for Optical Engineering Vol. 3777; Denver, CO, July, 1999; pp 144-155.

40. Martin, R. L.; Brancia, F. L. Analysis of High Mass Peptides Using a Novel Matrix-Assisted Laser Desorption/Ionization Quadrupole Ion Trap Time-of-Flight Mass Spectrometer. Rapid Commun. Mass Spectrom. 2003, 17, 1358-1365.

41. Lee, H.; Lubman, D. M. Sequence-Specific Fragmentation Generated by Matrix-Assisted Laser Desorption/Ionization in a Quadrupole Ion Trap/Reflectron Time-of-Flight Device. Anal. Chem. 1995, 67, 14001408.

42. Warrack, B. M.; Hail, M. E.; Triolo, A.; Animati, F.; Seraglia, R.; Traldi, P. Observation of Internal Monosaccharide Losses in the Collisionally Activated Dissociation Mass Spectra of Anthracycline Aminodisaccharides. J. Am. Soc. Mass Spectrom. 1998, 9, 710-715.

43. Hsu, F. F.; Turk, J. Characterization of Phosphatidylinositol, Phosphatidylinositol-4-Phosphate, and Phosphatidylinositol-4,5-Bisphosphate by Electrospray Ionization Tandem Mass Spectrometry: A Mechanistic Study. J. Am. Soc. Mass Spectrom. 2000, 11, 986-999.

44. Harvey, D. J.; Mattu, T. S.; Wormald, M. R.; Royle, L.; Dwek, R. A.; Rudd, P. M. Internal Residue Loss: Rearrangements Occurring During the Fragmentation of Carbohydrates Derivatized at the Reducing Terminus. Anal. Chem. 2002, 74, 734-740.

45. Chen, X.; Xing, J.; Zhong, D. Rearrangement Process Occurring in the Fragmentation of Adefovir Derivatives. J. Mass Spectrom. 2004, 39, 145-152.

46. Hsu, F. F.; Turk, J. Studies on Sulfatides by Quadrupole Ion-Trap Mass Spectrometry with Electrospray Ionization: Structural Characterization and the Fragmentation Processes That Include an Unusual Internal Galactose Residue Loss and the Classical Charge-Remote Fragmentation. J. Am. Soc. Mass Spectrom. 2004, 15, 536-546.

47. Marzian, S. Happel, M. Wagner, U. Mueller, D. Welzel, P. Fehlhaber, H.-W.; Staerk, A.; Schuetz, H.-J.; Markus, A.; Limbert, M.; van Heijenoort, Y.; van Heijenoort, J. Moenomycin A: Reactions at the Lipid Part. New Structure-Activity Relations. Tetrahedron 1994, 50, 5299-5308.

48. Kempin, U.; Hennig, L.; Welzel, P.; Marzian, S.; Mueller, D.; Fehlhaber, H.-W.; Markus, A.; van Heijenoort, Y.; van Heijenoort, J. Introduction of a Terminal Hydroxy Group into the Lipid Part of a Moenomycin-Type Transglycosylase Inhibitor Suppresses Antibiotic Activity. Tetrahedron $1995,51,8471-8482$. 